\title{
KELAYAKAN PENGEMBANGAN USAHA GULA SEMUT CV AGROBERDIKARI DI KECAMATAN SEMPOR, KABUPATEN KEBUMEN
}

\author{
Sarah Hanifa1), dan Nia Rosiana2) \\ 1)Program Sarjana Agribisnis, Fakultas Ekonomi dan Manajemen Institut Pertanian Bogor \\ 2)Departemen Agribisnis, Fakultas Ekonomi dan Manajemen Institut Pertanian Bogor \\ Jl. Kamper Wing 4 Level 5 Kampus IPB Dramaga Bogor, Indonesia \\ 1)e-mail: sarahhanifa17@gmail.com
}

(Diterima 29 Juli 2020 / Disetujui 16 Agustus 2020)

\begin{abstract}
Crystal sugar has a high potency to develop because of the growing demand for crystal sugar on a local and international scale. CV Agroberdikari is a company that produces crystal sugar in Kebumen District. The company needs investment to develop a development that increases the production of crystal sugar. Feasibility analysis needs to be done to see whether or not the business is executed when the company is developing based on non-financial aspects and financial aspects. Aspects assessed on non-financial aspects are market aspects, technical aspects, management and legal aspects, social and economic aspects, and environmental aspects. Assessment on financial aspects based on investment criteria of NPV, Net B/C, IRR and Payback Period and sensitivity analysis. Analysis results of non-financial aspects that the business is declared worthy to run. Analysis of financial aspects under normal conditions resulted in NPV Rp 708.012.338, Net B/C 2,64, IRR 29 per cent and PP 5,7 years. In development, conditions produce NPV Rp 1.003.257.059, Net B/C 3,74, IRR 45 per cent, and PP 4,9 year. The results of financial analysis can be stated that business development is worthy to run. The results of sensitivity analytic showed that the price increase of raw materials was more sensitive than the decrease in sugar production. Companies need to increase the number of suppliers of raw materials and add investment goods to increase consumer demand can be fulfilled and anticipate the increase of raw material prices.
\end{abstract}

Keywords: crystal sugar, feasibility, investment criteria, sensitivity

\begin{abstract}
ABSTRAK
Gula semut memiliki potensi yang tinggi untuk dikembangkan karena permintaan gula semut yang terus meningkat pada skala lokal maupun internasional. CV Agroberdikari merupakan perusahaan yang memproduksi gula semut di Kabupaten Kebumen. Perusahaan membutuhkan investasi untuk melakukan pengembangan yaitu meningkatkan produksi gula semut. Analisis kelayakan perlu dilakukan untuk melihat layak atau tidaknya usaha dijalankan bila perusahaan melakukan pengembangan berdasarkan aspek non finansial dan aspek finansial. Aspek yang dinilai pada aspek non finansial yaitu aspek pasar, aspek teknis, aspek manajemen dan hukum, aspek sosial dan ekonomi serta aspek lingkungan. Penilaian pada aspek finansial berdasarkan kriteria investasi yaitu NPV, Net B/C, IRR dan Payback Period serta analisis sensitivitas terhadap perubahan harga bahan baku dan jumlah produksi. Hasil analisis aspek non finansial bahwa usaha dinyatakan layak untuk dijalankan. Analisis aspek finansial pada kondisi normal menghasilkan NPV Rp 708.012.338, Net B/C 2,64, IRR 29 persen dan PP 5,7 tahun. Pada kondisi pengembangan menghasilkan NPV Rp 1.003.257.059, Net B/C 3,74, IRR 45 persen, dan PP 4,9 tahun. Hasil analisis finansial dapat dinyatakan bahwa pengembangan usaha layak untuk dijalankan. Hasil analisis sensitivitas menunjukkan bahwa kenaikan harga bahan baku lebih sensitif daripada penurunan produksi gula semut. Perusahaan perlu menambah jumlah pemasok bahan baku dan menambah barang investasi agar peningkatan permintaan konsumen dapat terpenuhi serta melakukan antisipasi terhadap kenaikan harga bahan baku.
\end{abstract}

Kata kunci: gula semut, kelayakan, kriteria investasi, sensitivitas 


\section{PENDAHULUAN}

Tanaman kelapa merupakan tanaman yang bernilai ekonomi tinggi karena hampir seluruh bagian tanaman kelapa dapat dimanfaatkan (Badiaroh 2013). Tanaman kelapa memiliki tinggi rata-rata 12,3 meter dan tanaman ini membutuhkan waktu 12 bulan dari mulai ditanam sampai berbuah (Suhardiyono 1995). Bunga tanaman ini disebut mayang letaknya ada diantara ketiak daun (Palungkun 2001). Salah satu produk dari tanaman kelapa adalah nira. Nira merupakan cairan dengan kadar gula tinggi yang disadap dari bunga kelapa. Salah satu produk yang dapat dikembangkan dari nira yaitu gula semut.

Gula semut atau sering disebut dengan gula kristal merupakan gula dari cairan nira yang diproses dan mempunyai hasil akhir berupa serbuk atau granular. Menurut Mustaufik dan Karseno (2004) gula semut memiliki kelebihan dibanding gula cetak yaitu aroma yang khas, kadar air 2-3 persen membuat umur penyimpanan yang lebih panjang, mudah larut dalam air, pengemasan yang praktis dan mudah dikombinasikan dengan bahan lain pada industri makanan dan minuman.

Gula semut memiliki prospek yang bagus karena gula semut sudah mencapai pasar internasional. Usaha pengolahan gula semut yang melakukan proses pengeringan dan bekerja sama dengan eksportir di Kabupaten Kebumen hanya ada satu yaitu CV Agroberdikari.

CV Agroberdikari merupakan satu-satunya perusahaan pengolahan gula semut di Kabupaten Kebumen yang sudah berbadan usaha. Perusahaan ini mendorong pengembangan agroindustri di Indonesia. Dimana agroindustri merupakan suatu kegiatan yang memproses dan mentransformasikan hasil pertanian menjadi produk setengah jadi maupun produk jadi yang langsung dapat dimanfaatkan oleh konsumen (Istiyanti et al, 2018). Adanya tingkat permintaan gula semut pasar luar negeri semakin meningkat. Hal ini mendorong perusahaan untuk meningkatkan produksi gula semut di CV Agroberdikari. Peningkatan produksi tersebut dapat dilihat pada Tabel 1.

${ }^{1}$ Hasil wawancara, tanggal 13 Oktober 2019 di pabrik gula semut CV Agroberdikari.
Tabel 1. Produksi Gula Semut CV Agroberdikari (Ton) Tahun 2017-2019

\begin{tabular}{cc}
\hline Tahun & Produksi (Ton) \\
\hline 2017 & 74 \\
2018 & 134 \\
2019 & 240 \\
\hline
\end{tabular}

Sumber : CV Agroberdikari (2019)

CV Agroberdikari menjalankan bisnis kewirausahaan sosial (social enterpreneurship) yaitu melakukan kerjasama dan kemitraan dengan petani gula semut. CV Agroberdikari mendapat pasokan gula semut dari petani gula semut yang menandatangani kontrak kerjasama dengan perusahaan. Gula semut yang telah terkumpul kemudian di oven, di ayak dan dilakukan proses sortasi di pabrik milik CV Agroberdikari. Pabrik CV Agroberdikari hanya dapat menampung gula semut sebanyak 20 ton.

Konsumen gula semut sebagian besar berasal dari luar negeri seperti Eropa, Amerika Serikat dan beberapa negara di Asia. Permintaan gula semut dari eksportir yang akan di ekspor mencapai 9 ton setiap bulan. Adanya permintaan gula semut yang meningkat dan semakin banyak pula petani gula semut yang bekerjasama dengan CV Agroberdikari membuat perusahaan ingin melakukan pengembangan usaha. Pengembangan yang akan dilakukan yaitu meningkatkan produksi hingga 35 ton $^{1}$. Akan tetapi, perusahaan belum bisa mengolah gula semut dalam jumlah besar karena perusahaan belum memiliki tempat penyimpanan atau gudang untuk produk yang sudah jadi. Perusahaan memiliki tanah di sekitar pabrik yang dapat diinvestasikan menjadi gudang penyimpanan untuk produk yang sudah jadi. Selain pembangunan gudang, perusahaan juga melakukan investasi dalam membeli alat-alat lain untuk menunjang proses produksi. Analisis kelayakan dilakukan agar pemilik dapat mengambil keputusan yang tepat, apakah perlu dilakukan pengembangan atau tidak.

CV Agroberdikari bergerak di industri gula semut. Adanya peningkatan permintaan gula semut menjadi bukti bahwa masih tersedia pasar untuk produk tersebut. Permintaan gula semut yang semakin meningkat membuat perusahaan harus meningkatkan produksinya. Oleh karena 
itu, perusahaan perlu mengetahui apakah mesin dan alat investasi lainnya mampu menunjang adanya kenaikan produksi. Keberhasilan suatu usaha tidak lepas dari manajemen perusahaan yang baik. Hal ini dapat dilihat dari adanya pembagian tugas yang jelas pada masing-masing jabatan di perusahaan dan perizinan usaha yang sudah dimiliki oleh perusahaan. Masyarakat dan lingkungan di sekitar lokasi usaha sudah seharusnya menjadi perhatian perusahaan agar usaha dapat berjalan dengan baik. Analisis pada aspek nonfinansial perlu dilakukan untuk melihat layak atau tidak bila usaha dikembangkan.

Perubahan pada harga input dan harga output yang terjadi pada usaha gula semut akan mempengaruhi kelayakan usaha. Gula semut basah merupakan bahan baku utama yang banyak menghabiskan biaya. Adanya peningkatan harga gula semut basah tentu akan berpengaruh terhadap kelayakan. Sedangkan output perusahaan yaitu gula semut, produksinya dapat menurun akibat keadaan cuaca. Apabila produksi gula semut mengalami penurunan, hal tersebut juga bisa mempengaruhi kelayakan. Analisis sensitivitas perlu dilakukan untuk melihat dampak dari perubahan-perubahan yang terjadi.

Berdasarkan uraian permasalahan diatas, maka tujuan permasalahan yang dikaji antara lain: 1) menganalisis kelayakan usaha gula semut di CV Agroberdikari dilihat dari aspek pasar, aspek teknis, aspek manajemen dan hukum, serta aspek sosial ekonomi lingkungan, 2) menganalisis kelayakan usaha gula semut di CV Agroberdikari dilihat dari aspek finansial, 3) menganalisis tingkat kepekaan usaha gula semut CV Agroberdikari terhadap adanya perubahan produksi gula semut dan perubahan harga bahan baku seperti nira kelapa.

\section{METODE PENELITIAN}

\section{LOKASI DAN WAKTU PENELITIAN}

Penelitian ini dilakukan di CV Agroberdikari yang terletak di Kecamatan Sempor, Kabupaten Kebumen, Jawa Tengah. Pemilihan lokasi penelitian dilakukan secara sengaja (purposive) dengan pertimbangan bahwa CV
Agroberdikari adalah produsen gula semut yang akan melakukan pengembangan yaitu meningkatkan produksi dan meningkatkan kapasitas gudang. CV Agroberdikari berencana akan melakukan pengembangan tersebut di tahun 2020, sehingga CV Agroberdikari sangat sesuai sebagai tempat penelitian yang khususnya untuk menganalisis studi kelayakan usaha. Pengumpulan data dilaksanakan pada bulan Desember 2019-Januari 2020.

\section{JENIS DAN SUMBER DATA}

Jenis data yang digunakan dalam penelitian ini adalah data primer dan data sekunder. Data primer diperoleh melalui pengamatan langsung dan wawancara. Teknik pengumpulan data primer dilakukan dengan cara wawancara kepada pendiri CV Agroberdikari dan pengamatan langsung kegiatan-kegiatan yang dilakukan di perusahaan CV Agroberdikari. Pengisian kuesioner skala likert dilakukan oleh lima responden yang terdiri dari satu orang manajer, tiga orang tim ICS (Internal Control System) dan satu orang staff administrasi.

Data sekunder merupakan informasi tambahan sebagai penunjang penelitian. Data sekunder diperoleh dari kumpulan data yang dimiliki pihak pemilik, bahan-bahan pustaka, situs internet, laporan penelitian, data-data dari instansi terkait, baik dari Kementerian Pertanian, Kementerian Perdagangan, Pemerintah Daerah, Dinas Pertanian, Dinas Perindustrian dan Perdagangan serta Badan Pusat Statistik.

\section{METODE ANALISIS DATA}

Analisis data yang digunakan dalam penelitian ini dilakukan secara kualitatif dan kuantitatif. Data yang bersifat kualitatif dianalisis untuk mengkaji beberapa aspek, aspek-aspek yang dianalisis ini adalah aspek teknis, pasar, dan manajemen. Analisis kuantitatif dilakukan dengan menganalisis aspek finansial dan non finansial pada pengolahan gula semut CV Agroberdikari. Analisis aspek finansial dilakukan dengan menggunakan kriteria kelayakan investasi dan analisis aspek nonfinansial menggunakan skala likert yaitu dengan memberikan skor pada item yang tersedia di masing-masing aspek. 


\section{a. Aspek Pasar}

Analisis kualitatif aspek pasar meliputi analisis permintaan, penawaran, harga, perkiraan penjualan yang bisa dicapai perusahaan dan program pemasaran. Analisis kuantitatif pada aspek pasar dilakukan dengan memberi skor pada item-item yang tersedia. Usaha gula semut CV Agroberdikari dikatakan layak bila terdapat permintaan dan penawaran yang baik di pasar, harga produk mampu bersaing, serta terpenuhinya bauran pemasaran seperti produk, harga, promosi, dan distribusi. (Nurmalina et al 2014).

\section{b. Aspek Teknis}

Analisis kualitatif aspek teknis meliputi pengoperasian pada usaha pengolahan gula semut. Analisis kuantitatif pada aspek teknis dilakukan dengan memberi skor pada item-item yang tersedia. Usaha tersebut dapat dikatakan layak dalam aspek teknis bila lokasi perusahaan mampu mendukung kegiatan usaha dalam hal luas produksi sudah optimal, lokasi usaha yang mendukung, layout perusahaan yang sesuai sehingga mampu memperlancar proses produksi, pemilihan teknologi sudah tepat (Nurmalina 2014).

\section{c. Aspek Manajemen-Hukum}

Aspek manajemen pada usaha Analisis kualitatif aspek manajemen dan hukum pada usaha pengolahan gula semut dikatakan layak apabila menggunakan sistem manajemen yang baik seperti adanya stuktur organisasi serta adanya pembagian dan deskripsi tugas yang jelas dari masing-masing jabatan yang ada. Analisis kuantitatif pada aspek manajemen dan hukum dilakukan dengan memberi skor pada item-item yang tersedia. Menurut Subagyo (2008) suatu usaha dikatakan layak secara aspek hukum jika usaha tersebut legal. Legal atau ilegalnya suatu perusahaan ditentukan oleh ada tidaknya surat izin untuk mendirikan usaha.

\section{d. Aspek Sosial-Ekonomi}

Aspek sosial-ekonomi pada usaha pengolahan gula semut dikatakan layak jika memberi dampak positif terhadap penghasilan negara, berpengaruh terhadap devisa negara, membuka peluang kerja, dan berdampak positif terhadap pengembangan wilayah dimana usaha tersebut dijalankan (Gittinger 1986). Analisis kuantitatif pada aspek sosial dan ekonomi dilakukan dengan memberi skor pada item-item yang tersedia.

\section{e. Aspek Lingkungan}

Aspek lingkungan pada usaha pengolahan gula semut dikatakan layak apabila tidak menghasilkan limbah yang dapat memberikan dampak yang negatif terhadap lingkungan (Husnan dan Muhammad 2000). Analisis kuantitatif pada aspek lingkungan dilakukan dengan memberi skor pada item-item yang tersedia.

Penggunaan analisis kuantitatif pada aspek non finansial bertujuan untuk mempermudah dalam menganalisis kelayakannya. Analisis kuantitatif dilakukan dengan cara penilaian skor kelayakan berdasarkan skala dari satu sampai lima (1-5). Pilihan jawaban disusun berjenjang dari pilihan sangat tidak setuju (1) sampai sangat setuju (5). Penilaian dilakukan berdasarkan itemitem yang telah ditentukan yang akan menggambarkan secara lebih rinci apakah keseluruhan aspek non finansial mencakup aspek pasar, aspek teknis, aspek manajemen dan hukum, aspek sosial ekonomi, dan aspek lingkungan memenuhi standar dan usaha tersebut layak untuk dijalankan (Wahyu 2018).

Perhitungan awal untuk mengetahui presentase tingkat kelayakan yaitu mengetahui jumlah skor tertinggi (ST tot). ST tot didapatkan dari skala tertinggi (NT) dikalikan dengan jumlah pertanyaan (Qtot) dan dikalikan dengan total pengguna (Ptot). Perhitungan kedua yaitu mengetahui presentase akhir (Pre) yang diperoleh dari jumlah skor hasil pengumpulan data (JSA) dibagi jumlah skor tertinggi (ST tot) dikalikan 100 persen (Lemantara dan Windarti 2014) Persentase tingkat kelayakan pada Tabel 2 dapat diketahui bahwa usaha layak dijalankan bila presentase diatas 60 persen.

ST tot $=$ NT $x$ Qtot $x$ Ptot

Pre $=\frac{\mathrm{JSA}}{\mathrm{ST} \text { tot }} \times 100 \%$. 
Tabel 2. Persentase Tingkat Kelayakan Aspek Non Finansial

\begin{tabular}{cc}
\hline Presentase (\%) & Tingkat Kelayakan \\
\hline $20-39.99$ & Sangat tidak layak \\
$40-59.99$ & Tidak layak \\
$60-79.99$ & Cukup layak \\
$80-99.99$ & Layak \\
100 & Sangat layak \\
\hline Sumber : Lemantara dan Windarti (2014)
\end{tabular}

\section{f. Aspek Finansial}

Analisis finansial dilakukan dengan membandingkan kondisi normal yaitu kondisi saat ini yang belum melakukan pengembangan dan kondisi pengembangan. Usaha yang dijalankan saat ini belum pernah dilakukan analisis kelayakan. Penambahan investasi karena adanya pengembangan usaha memerlukan modal yang besar sehingga perusahaan perlu melakukan analisis kelayakan dari sisi aspek finansial. Dengan membandingkan kriteria investasi pada kondisi normal dan kondisi pengembangan, perusahaan dapat mengambil keputusan apakah pengembangan usaha layak dijalankan atau tidak. Analisis finansial dilakukan dengan mengolah data menggunakan kriteria kelayakan investasi, yaitu : Analisis Nilai Bersih Sekarang (Net Present Value/NPV), Tingkat Pengembalian Investasi (Internal Rate of Return/IRR), Rasio Manfaat dan Biaya Bersih (Net Benefit Cost Ratio/Net B/C), Masa Pengembalian Investasi yang didiskontokan (Discounted Payback Period).

\section{1) Net Present Value (NPV)}

Suatu bisnis dikatakan layak jika jumlah seluruh manfaat yang diterima melebihi biaya yang dikeluarkan. Selisih antara manfaat dan biaya disebut dengan manfaat bersih.Suatu bisnis dikatakan layak jika NPV lebih besar dari 0 yang artinya bisnis menguntungkan atau memberikan manfaat. NPV adalah selisih antara total present value manfaat dengan total present value biaya. Secara matematis, NPV dapat dihitung dengan menggunakan rumus sebagai berikut (Nurmalina et al 2014).

$\mathrm{NPV}=\sum_{\mathrm{t}=0 / 1}^{\mathrm{n}} \frac{\mathrm{Bt}-\mathrm{Ct}}{(1+\mathrm{i})^{\mathrm{t}}}$
Dimana :

$\mathrm{Bt}=$ Manfaat pada tahun ke $\mathrm{t}$ (Rupiah)

$\mathrm{Ct}=$ Biaya pada tahun ke $\mathrm{t}$ (Rupiah)

$\mathrm{t}=$ Tahun kegiatan bisnis (tahun)

$\mathrm{i}=$ Tingkat DR (discount rate) (persen)

2) Net Benefit-Cost Ratio (Net B/C)

Net B/C adalah rasio antara manfaat bersih yang bernilai positif dengan manfaat bersih yang bernilai negatif. Manfaat bersih yang menguntungkan bisnis yang dihasilkan terhadap setiap satu satuan kerugian dari bisnis tersebut. Suatu bisnis atau kegiatan investasi dapat dikatakan layak jika nilai Net B/C lebih besar dari 1. Secara matematis, Net B/C ratio dapat dihitung dengan menggunakan rumus berikut (Nurmalina et al 2014).

Net $\mathrm{B} / \mathrm{C}=\frac{\sum_{\mathrm{t}=0 / 1}^{\mathrm{n}} \frac{\mathrm{Bt}-\mathrm{Ct}}{(1+\mathrm{i})^{\mathrm{t}}}}{\sum_{\mathrm{t}=0 / 1}^{\mathrm{n}} \frac{\mathrm{Bt}-\mathrm{Ct}}{(1+i)^{\mathrm{t}}}}$

Dimana :

$\mathrm{Bt}=$ Manfaat pada tahun ke $\mathrm{t}$ (Rupiah)

$\mathrm{Ct}=$ Biaya pada tahun ke $\mathrm{t}$ (Rupiah)

$\mathrm{n}=$ Jumlah tahun

$\mathrm{t}=$ Tahun kegiatan bisnis(tahun)

$\mathrm{i}=$ Tingkat DR (discount rate) (persen)

3) Internal Rate of Return (IRR)

Menilai seberapa besar pengembalian bisnis terhadap investasi yang ditanamkan. IRR adalah tingkat discount rate (DR) yang menghasilkan NPV sama dengan 0. Perhitungan IRR umumnya dilakukan dengan menggunakan metode interpolasi diantara tingkat discount rate yang lebih rendah (yang menghasilkan NPV positif) dengan tingkat discount rate yang lebih tinggi (yang menghasilkan NPV negatif). Secara matematis, IRR dapat dihitung dengan menggunakan rumus berikut (Nurmalina et al., 2014).

$\mathrm{IRR}=\mathrm{i}_{1}+\frac{\mathrm{NPV}_{1}}{\mathrm{NPV}_{1}-\mathrm{NPV}_{2}}\left(\mathrm{i}_{2}-\mathrm{i}_{1}\right)$

Di mana :

$\mathrm{NPV}_{1}=\mathrm{NPV}$ positif

$\mathrm{NPV}_{2}=\mathrm{NPV}$ negatif

$\mathrm{i}_{1} \quad=$ Discount rate yang menghasilkan NPV positif (persen)

$\mathrm{i}_{2}=$ Discount rate yang menghasilkan NPV negatif (persen) 
4) Payback Period

Payback Period adalah metode yang digunakan untuk mengukur seberapa cepat investasi bisa kembali. Bisnis yang PP-nya singkat atau cepat pengembaliannya termasuk bisnis yang kemungkinan besar akan dipilih. Secara matematis, PP dapat dihitung dengan menggunakan rumus berikut (Nurmalina et al., 2014).

$$
\mathrm{PP}=\frac{\mathrm{I}}{\mathrm{Ab}}
$$

Di mana :

$\mathrm{i}$ = Besarnya investasi yang dibutuhkan (Rupiah)

$\mathrm{Ab}=$ Manfaat bersih yang dapat diperoleh setiap tahun.

Jika masa pengembalian investasi (Payback Period) lebih singkat daripada umur proyek yang ditentukan, maka proyek tersebut layak untuk dilaksanakan. Pada dasarnya semakin cepat Payback Period menunjukan semakin kecil risiko yang dihadapi oleh investor (pengusaha).

\section{g. Analisis Sensitivitas}

Analisis sensitivitas dilakukan dengan cara mengubah besarnya variabel-variabel yang penting, masing-masing dapat terpisah atau beberapa dalam kombinasi dengan suatu presentase tertentu yang sudah diketahui atau diprediksi. Kemudian dinilai seberapa besar sensitivitas perubahan variabel-variabel tersebut berdampak pada hasil kelayakan (NPV, IRR, Net B/C) (Nurmalina et al 2014). Dalam melaksanakan analisis sensitivitas terdapat dua kondisi. Kondisi pertama terjadi penurunan produksi gula semut sebesar 15 persen. Hal ini didasarkan pada pengalaman perusahaan pada tahun 2019. Kondisi kedua terjadi kenaikan biaya produksi sebesar 3,41 persen, hal ini berdasarkan inflasi yang terjadi pada tahun 2019 .

\section{ASUMSI DASAR}

1. Seluruh modal yang digunakan dalam usaha pengolahan gula semut CV Agroberdikari berasal dari modal sendiri

2. Umur usaha adalah 10 tahun, penetapan umur usaha ini didasarkan pada umur ekonomis dari variabel investasi terlama yaitu mesin oven.
3. Output yang dihasilkan oleh CV Agroberdikari yaitu gula semut kemasan $25 \mathrm{~kg}$ serta kemasan 300 gram yang berbentuk pouch dan tabung.

4. Bahan baku berupa gula semut basah didapatkan dari kelompok tani di Kabupaten Kebumen yang bermitra dengan CV Agroberdikari.

5. Harga input dan output yang digunakan dalam analisis merupakan harga yang berlaku pada saat penelitian tahun 2019 dan diasumsikan konstan.

6. Penyusutan barang investasi dihitung menggunakan metode garis lurus.

7. Tingkat diskonto yang digunakan merupakan tingkat suku bunga deposito bank BRI pada bulan Desember 2019 yaitu 5,25 persen.

8. Pajak pendapatan yang digunakan berdasarkan Undang-Undang Republik Indonesia No. 36 tahun 2008, pasal 17 ayat 2 a dan 31 E, yang merupakan perubahan keempat atas undangundang nomor 7 tahun 1983 tentang pajak penghasilan, yaitu:

- Pasal 17 ayat 1 b. Wajib Pajak badan dalam negeri dan bentuk usaha tetap adalah sebesar 28\% (dua puluh delapan persen).

- Pasal 17 ayat 2 a. Tarif sebagaimana dimaksud pada ayat (1) huruf b menjadi $25 \%$ (dua puluh lima persen) yang mulai berlaku sejak tahun pajak 2010.

\section{HASIL DAN PEMBAHASAN}

\section{GAMBARAN UMUM PERUSAHAAN}

CV Agroberdikari didirikan pada tahun 2013 oleh Bapak Hartanto Wicaksono. Pak Hartanto kemudian memulai bisnis gula semut di tahun 2013 dengan menggunakan modal awal sebesar 70 juta yang berasal dari modal pribadi. Modal tersebut digunakan untuk menyewa tempat pengolahan dan membeli mesin. Pada tahun 2014, perusahaan sudah berbadan usaha yaitu CV (Commanditaire Vennootschap). CV ini kemudian diberi nama CV Agroberdikari. Awal berdirinya perusahaan, Pak Hartanto menyewa sebuah tempat di dekat pabrik yang saat ini berdiri. Kemudian di tahun 2018 perusahaan memiliki bangunan pabrik sendiri sehingga tidak lagi menyewa.

Usaha gula semut CV Agroberdikari terletak di Desa Sempor, Kecamatan Sempor. Lokasi 
usaha cukup strategis karena terletak di dekat jalan alternatif yang menghubungkan Kabupaten Kebumen dan Kabupaten Banjarnegara. Selain itu, lokasi usaha juga berdekatan dengan Waduk Sempor yang merupakan tempat wisata, PLTA dan penyedia kebutuhan air bagi masyarakat sekitar waduk. Usaha gula semut di Kabupaten Kebumen yang sudah berbadan usaha hanya ada satu yaitu CV Agroberdikari.

CV Agroberdikari memiliki struktur organisasi yang masih sederhana. Bapak Hartanto Wicaksono selaku pemilik perusahaan menduduki jabatan sebagai manajer perusahan. Ibu Rini yang merupakan istri dari pemilik perusahaan, menduduki posisi direktur. Pada bagian administrasi, tim ICS, kepala produksi diberikan kepada orang yang sudah terlatih dan dipercaya oleh pemilik perusahaan. Sedangkan untuk merekrut karyawan sortir dan oven, perusahaan tidak memiliki persyaratan khusus. Kesempatan kerja tersebut hanya diinformasikan saja kepada masyarakat sekitar perusahaan.

Produk gula semut milik CV Agroberdikari diberi nama Gula Semut Moyang. CV Agroberdikari mengolah gula semut dari petani menjadi gula semut yang berkualitas sehingga memenuhi standar untuk ekspor. Gula semut tersebut dikemas dalam beberapa kemasan yang disesuaikan dengan kebutuhan konsumen. Kemasan $25 \mathrm{~kg}$ menggunakan plastik khusus dalam pengemasannya. Kemasan ini diperuntukkan bagi konsumen yang membeli dalam jumlah besar seperti eksportir dan pabrik minuman. Perusahaan juga membuat kemasan pouch dan tabung yang berisikan gula semut seberat 300 gram. Kemasan ini diperuntukkan bagi konsumen lokal yang membeli secara langsung dalam jumlah sedikit. Kemasan pouch menggunakan plastik zip lock sedangkan kemasan tabung menggunakan karton tebal yang dibentuk menjadi tabung. Kemasan diberi label yang diberi keterangan seperti nama produk, nomor izin, dan komposisi gula.

Sebagian besar produk gula semut yang berukuran $25 \mathrm{~kg}$ dibeli oleh perusahaan besar untuk di ekspor. Perusahaan tersebut yaitu PT Aldin Pacific Semesta, CV Manna, dan PT Profil Mitra Abadi. CV Agroberdikari juga menjual produk gula semut secara langsung ke konsumen.
Gula semut dengan kemasan 300 gram dijual di beberapa tempat yang menjual produk ungulan dari Kabupaten Kebumen seperti Dekranasda, Martha Tilaar, dan Hotel Mexolie. Gula semut kelapa dari CV Agroberdikari berasal dari nira kelapa organik sehingga lebih sehat dibandingkan dengan gula biasa. Kelebihan produk gula semut dari CV Agroberdikari yaitu kualitasnya bagus ditandai dengan aroma khas dan warna yang cerah serta kadar air dibawah 5 persen. Selain itu gula semut CV Agroberdikari sudah tersertifkasi organik dari EU (European Union) dan USDA (United States Department of Agriculture). Harga gula semut tergantung pada kemasannya. Harga gula semut dengan kemasan $25 \mathrm{~kg}$ yaitu $\mathrm{Rp}$ 22.000 per $\mathrm{kg}$, kemasan pouch 300 gram yaitu Rp 13.000 dan kemasan tabung 300 gram yaitu $\mathrm{Rp}$ 20.000 .

Perusahaan bekerja sama dengan Dinas Pertanian untuk mempromosikan produknya. Produk gula semut akan dibawa oleh dinas untuk ikut dalam pameran. Produk gula semut dari CV Agroberdikari dipasarkan ke beberapa konsumen yaitu eksportir, pabrik minuman, cafe, reseller dan konsumen akhir.

\section{ASPEK NON FINANSIAL}

\section{a. Aspek Pasar}

Hasil analisis aspek pasar CV Agroberdikari diperoleh informasi bahwa permintaan gula semut CV Agroberdikari dapat memenuhi sebagian besar permintaan konsumen serta permintaan gula semut yang kontinu dan terus meningkat. Strategi bauran pemasaran (4P) diterapkan dengan baik sehingga mampu menarik perhatian konsumen. Hasil penilaian skor kelayakan pada Lampiran 1 diperoleh presentase sebesar 90 persen yang masuk dalam kategori layak. Berdasarkan analisis kualitatif dan kuantitatif yang telah dilakukan, pengembangan usaha gula semut CV Agroberdikari layak untuk dijalankan.

\section{b. Aspek Teknis}

Lokasi pengolahan gula semut CV Agroberdikari beralamat di Desa Sempor RT 04/01 Kecamatan Sempor, Kabupaten Kebumen. Lokasinya sangat strategis karena letak pabrik berada di jalan alternatif yang menghubungkan 
Kabupaten Kebumen dan Kabupaten Banjarnegara. Perusahaan bermitra dengan petani yang ada di delapan desa untuk memasok bahan baku yang lokasinya berada di kecamatan lain di sekitar lokasi usaha.

Produksi gula semut sangat bergantung pada listrik. Apabila listrik padam, maka proses produksi tidak dapat dilakukan. Akan tetapi, lokasi usaha sangat jarang terjadi pemadaman listrik. Air yang digunakan oleh CV Agroberdikari berasal dari PDAM dan sumur. Sehingga dapat dikatakan ketersediaan air untuk operasional perusahaan aman. Sebagian besar tenaga kerja di perusahaan merupakan masyarakat yang ada di sekitar lokasi usaha.

Layout produksi CV Agroberdikari cukup sederhana karena semua ruangan saling terhubung dan berada dalam satu pabrik. meskipun sederhana, proses produksi tetap dapat berjalan dengan baik. Proses produksi di CV Agroberdikari menggunakan mesin dan manual yang dapat dengan mudah dioperasikan oleh karyawan.

Hasil analisis aspek teknis dapat diketahui bahwa lokasi usaha gula semut CV Agroberdikari cukup strategis dekat dengan pasar dan bahan baku. Pabrik gula semut memiliki layout yang cukup sederhana, namun tidak ada kendala dalam proses produksi gula semut. Proses produksi sesuai standar dengan menggunakan mesin sederhana yang ramah lingkungan sehingga mudah dioperasikan oleh karyawan. Hasil penilaian skor kelayakan pada Lampiran 2 diperoleh presentase sebesar 85 persen yang masuk dalam kategori layak. Berdasarkan analisis kualitatif dan kuantitatif yang telah dilakukan, pengembangan usaha gula semut CV Agroberdikari layak untuk dijalankan.

\section{c. Aspek Manajemen dan Hukum}

Usaha pengolahan gula semut memerlukan suatu manajemen dan izin usaha agar usaha dapat berjalan dengan baik. CV Agroberdikari sudah memiliki struktur organisasi yang sederhana namun tetap berjalan dengan baik sesuai dengan deskripsi pekerjaan. CV Agroberdikari melakukan pembagian gaji sesuai dengan posisi masingmasing.

Bentuk usaha dari perusahaan gula semut adalah Comanditer Vereigne (CV). Perusahaan sudah memiliki beberapa izin pendirian usaha dan sertifikat dalam menjalankan usaha. Izin pendirian usaha yang dimiliki antara lain Akta Pendirian, TDP, SIUP, dan izin dari Depkes. Sertifikat yang dimiliki oleh perusahaan yaitu sertifikat organik dan sertifikat halal dari MUI. Oleh karena itu perusahaan telah memenuhi hukum dan peraturan sehingga perusahaan dapat menjalankan usahanya dengan lancar.

Berdasarkan hasil wawancara dapat diketahui bahwa CV Agroberdikari sudah memiliki struktur organisasi. Meskipun sederhana, sudah ada pembagian tugas yang jelas pada masingmasing posisi. CV Agroberdikari tidak memiliki kendala dalam perizinan karena sudah memiliki izin usaha dan beberapa sertifikat. Bentuk usaha perusahaan juga sudah jelas yaitu persekutuan komanditer.

Hasil penilaian skor kelayakan pada Lampiran 3 diperoleh presentase sebesar 86,8 persen yang masuk dalam kategori layak. Berdasarkan analisis kualitatif dan kuantitatif yang telah dilakukan, pengembangan usaha gula semut CV Agroberdikari layak untuk dijalankan.

\section{d. Aspek Sosial dan Ekonomi}

Keberadaan usaha pengolahan gula semut CV Agroberdikari memberikan dampak positif kepada masyarakat. Secara sosial, usaha ini mampu memberi manfaat kepada masyarakat yaitu terserapnya tenaga kerja dari masyarakat di sekitar lokasi usaha. Jumlah tenaga kerja yang diserap oleh perusahaan berjumlah 24 orang. Penyerapan tenaga kerja ini mampu mengurangi pengangguran dan meningkatkan perekonomian masyarakat. Usaha ini juga mendapat dukungan dari masyarakat karena mematuhi aturan dan kebiasaan yang ada di masyarakat. CV Agroberdikari membayar pajak kepada pemerintah yang menunjukkan bahwa perusahaan turut berkontribusi pada perekonomian daerah secara keseluruhan.

Berdasarkan analisis aspek sosial dan ekonomi, usaha pengolahan gula semut dapat diterima dengan baik oleh masyarakat di sekitar lokasi usaha. Keberadaan CV Agroberdikari mampu mengurangi pengangguran dan meningkatkan kesejahteraan masyarakat. Lapangan kerja menjadi bertambah karena adanya usaha gula 
semut. Hasil penilaian skor kelayakan pada Lampiran 4 diperoleh presentase sebesar 81,33 persen yang masuk dalam kategori layak. Berdasarkan analisis kualitatif dan kuantitatif yang telah dilakukan, pengembangan usaha gula semut CV Agroberdikari layak untuk dijalankan.

\section{e. Aspek Lingkungan}

Aspek lingkungan perlu diperhatikan dalam menjalankan usaha untuk mengetahui dampak yang ditimbulkan oleh adanya usaha terhadap lingkungan. Berdasarkan hasil observasi, perusahaan tidak menghasilkan limbah yang dapat membahayakan lingkungan. Masyarakatpun tidak merasa terganggu dengan adanya pabrik tersebut.

Berdasarkan hasil observasi dan wawancara diperoleh informasi bahwa usaha pengolahan gula semut hampir tidak menghasilkan limbah baik dalam bentuk padat, cair maupun gas. Selain itu, mesin yang digunakan merupakan mesin sederhana yang tidak menghasilkan polusi udara. Keberadaan usaha gula semut tidak membahayakan lingkungan. Hasil penilaian skor kelayakan pada Lampiran 5 diperoleh presentase sebesar 78,4 persen yang masuk dalam kategori layak. Berdasarkan analisis kualitatif dan kuantitatif yang telah dilakukan, pengembangan usaha gula semut CV Agroberdikari layak untuk dijalankan.

\section{ASPEK FINANSIAL}

\section{a. Kondisi Normal}

Hasil perhitungan kriteria investasi pada Tabel 3 diperoleh NPV sebesar Rp 708.012.338. Hal ini menunjukkan bahwa manfaat bersih yang diterima oleh CV Agroberdikari dalam kurun waktu 10 tahun yaitu sebesar Rp 708.012.338 pada tingkat discount rate 5,25 persen. Dengan demikian, berdasarkan kriteria NPV usaha ini layak untuk dijalankan karena NPV lebih besar dari nol. Perhitungan Net B/C pada keadaan normal sebesar 2,64. Artinya, setiap satu rupiah biaya yang dikeluarkan untuk menjalankan usaha gula semut akan menghasilkan keuntungan sebesar 2,64 rupiah. Nilai Net B/C yang dihasilkan lebih dari satu, sehingga berdasarkan kriteria Net B/C usaha ini layak untuk dijalankan.

Pada kondisi normal, hasil perhitungan IRR sebesar 29 persen. Nilai IRR yang diperoleh menunjukkan hasil yang lebih besar daripada discount rate (5,25 persen). Artinya, tingkat pengembalian investasi pada usaha gula semut sebesar 29 persen. Nilai IRR tersebut menunjukkan bahwa perusahaan akan mendapat keuntungan lebih besar jika melakukan investasi pada usaha gula semut dibandingkan dengan menyimpan dana investasi untuk didepositokan atau ditabung. Dengan demikian, usaha ini layak untuk dijalankan. Perhitungan kriteria investasi yang terakhir yaitu Payback Period diperoleh hasil sebesar 5,7. Hal ini menunjukkan bahwa jangka waktu pengembalian seluruh investasi yang ditanamkan pada usaha gula semut yaitu selama 5 tahun 7 bulan. Dapat disimpulkan bahwa usaha ini layak untuk dijalankan karena payback period yang lebih pendek dari umur usaha (10 tahun).

\section{Tabel 3. Hasil Perhitungan Kriteria Investasi pada Kondisi Normal}

\begin{tabular}{lc}
\hline Kriteria Investasi & Hasil Perhitungan \\
\hline NPV (Rp) & 708.012 .338 \\
Net B/C & 2.64 \\
IRR (\%) & 29 \\
Payback Period & 5.7 \\
\hline
\end{tabular}

\section{b. Kondisi Pengembangan}

Hasil perhitungan kriteria investasi pada Tabel 4 diperoleh NPV sebesar Rp 1.003.257.059. Hal ini menunjukkan bahwa manfaat bersih yang diterima oleh CV Agroberdikari dalam kurun waktu 10 tahun yaitu sebesar Rp 1.003.257.059 pada tingkat discount rate 5,25 persen. Dengan demikian, berdasarkan kriteria NPV usaha ini layak untuk dijalankan karena NPV lebih besar dari nol. Perhitungan Net B/C pada keadaan pengembangan sebesar 3,74. Artinya, setiap satu rupiah biaya yang dikeluarkan untuk menjalankan usaha gula semut akan menghasilkan keuntungan sebesar 3,74 rupiah. Nilai Net B/C yang dihasilkan lebih dari satu, sehingga berdasarkan kriteria Net B/C usaha ini layak untuk dijalankan.

Pada kondisi pengembangan, hasil perhitungan IRR sebesar 45 persen. Nilai IRR yang diperoleh menunjukkan hasil yang lebih besar daripada discount rate (5,25 persen). Artinya, tingkat pengembalian investasi pada usaha gula semut sebesar 45 persen. Nilai IRR tersebut menunjukkan bahwa perusahaan akan mendapat keuntungan lebih besar jika melakukan investasi pada usaha gula semut dibandingkan dengan 
menyimpan dana investasi untuk didepositokan atau ditabung. Dengan demikian, usaha ini layak untuk dijalankan. Perhitungan kriteria investasi yang terakhir yaitu Payback Period diperoleh hasil sebesar 4,9. Hal ini menunjukkan bahwa jangka waktu pengembalian seluruh investasi yang ditanamkan pada usaha gula semut yaitu selama 4 tahun 9 bulan. Dapat disimpulkan bahwa usaha ini layak untuk dijalankan karena payback period yang lebih pendek dari umur usaha (10 tahun).

Tabel 4. Hasil Perhitungan Kriteria Investasi pada Kondisi Pengembangan

\begin{tabular}{lc}
\hline Kriteria Investasi & Hasil Perhitungan \\
\hline NPV (Rp) & 1.003 .257 .059 \\
Net B/C & 3.74 \\
IRR (\%) & 45 \\
Payback Period & 4.9 \\
\hline
\end{tabular}

Hasil analisis finansial pada kondisi normal dan kondisi pengembangan menunjukkan bahwa usaha layak dijalankan pada kedua kondisi tersebut. Akan tetapi, semua kriteria investasi pada kondisi pengembangan menunjukkan hasil yang lebih tinggi dibandingkan pada kondisi normal. Berdasarkan analisis pada aspek finansial yang telah dilakukan, pengembangan usaha gula semut CV Agroberdikari layak untuk dijalankan.

\section{ANALISIS SENSITIVITAS}

Analisis sensitivitas digunakan untuk mengetahui dampak yang ditimbulkan dari keadaan yang berubah-ubah. Terdapat dua variabel yang digunakan untuk melakukan analisis sensitivitas yaitu penurunan produksi gula semut dan peningkatan harga bahan baku. Besar penurunan produksi gula semut yaitu 15 persen. Asumsi ini berdasarkan pengalaman perusahaan ketika musim hujan pasokan bahan baku mengalami penurunan. Sedangkan besar peningkatan harga bahan baku yaitu 3.41 persen. Asumsi ini berdasarkan tingkat inflasi yang terjadi di tahun 2019. Hasil perhitungan analisis sensitivitas pada kondisi normal dapat dilihat pada Tabel 5.

Hasil analisis sensitivitas pada kondisi normal menunjukkan bahwa penurunan produksi gula semut sebesar 15 persen membuat usaha tetap layak dijalankan. Nilai NPV yang dihasilkan lebih dari nol yaitu sebesar Rp 193.347.940.
Sedangkan, pada peningkatan harga bahan baku sebesar 3,41 persen, nilai NPV yang dihasilkan sebesar Rp -208.355.219. Berdasarkan hasil tersebut, usaha dikatakan tidak layak untuk dijalankan karena nilai NPV lebih kecil dari nol.

Tabel 5. Hasil Perhitungan Analisis Sensitivitas pada Kondisi Normal

\begin{tabular}{lcrc}
\hline \multicolumn{1}{c}{ Variabel } & NPV (Rp) & $\begin{array}{l}\text { IRR } \\
\text { (\%) }\end{array}$ & $\begin{array}{l}\text { Net } \\
\text { B/C }\end{array}$ \\
\hline $\begin{array}{l}\text { Penurunan } \\
\text { produksi gula } \\
\text { semut 15\% }\end{array}$ & 193.347 .940 & 9 & 1,43 \\
$\begin{array}{l}\text { Peningkatan } \\
\text { harga bahan } \\
\text { baku 3,41\% }\end{array}$ & -208.355 .219 & -10 & 0,57 \\
\hline
\end{tabular}

Hasil analisis sensitivitas pada kondisi pengembangan (Tabel 6) menunjukkan bahwa penurunan produksi gula semut sebesar 15 persen membuat usaha tetap layak dijalankan. Nilai NPV yang dihasilkan lebih dari nol yaitu sebesar Rp 418.758.223. Sedangkan, pada peningkatan harga bahan baku sebesar 3,41 persen, nilai NPV yang dihasilkan sebesar Rp -351.674.568. Berdasarkan hasil tersebut, usaha dikatakan tidak layak untuk dijalankan karena nilai NPV lebih kecil dari nol.

Tabel 6. Hasil Perhitungan Analisis Sensitivitas pada Kondisi Pengembangan

\begin{tabular}{lccc}
\hline \multicolumn{1}{c}{ Variabel } & NPV (Rp) & $\begin{array}{l}\text { IRR } \\
\text { (\%) }\end{array}$ & $\begin{array}{l}\text { Net } \\
\text { B/C }\end{array}$ \\
\hline $\begin{array}{l}\text { Penurunan } \\
\text { produksi gula } \\
\text { semut 15\% }\end{array}$ & 418.758 .223 & 19 & 2.03 \\
$\begin{array}{l}\text { Peningkatan } \\
\text { harga bahan } \\
\text { baku 3,41\% }\end{array}$ & -351.674 .568 & -22 & 0.27 \\
\hline
\end{tabular}

\section{SIMPULAN DAN SARAN}

\section{SIMPULAN}

1. Berdasarkan hasil analisis pada aspek non finansial yang meliputi aspek pasar, aspek teknis, aspek manajemen dan hukum, aspek sosial dan ekonomi serta aspek lingkungan, pengembangan usaha gula semut $\mathrm{CV}$ Agroberdikari dapat dikatakan layak untuk dijalankan. 
2. Hasil analisis aspek finansial pada usaha gula semut CV Agroberdikari menunjukkan bahwa pengembangan yang akan dilakukan oleh perusahaan layak untuk dijalankan karena kriteria investasi pada kondisi pengembangan lebih besar dibandingkan kondisi normal.

3. Hasil analisis sensitivitas menunjukkan bahwa kondisi normal lebih sensitif terhadap penurunan produksi dibandingkan kondisi pengembangan.

\section{SARAN}

1. Perlunya penambahan jumlah pemasok bahan baku melalui sistem kerjasama yang saling menguntungkan kedua belah pihak sehingga dapat mendorong peningkatan nilai ekonomi perusahaan dan pemasok sehingga pemenuhan permintaan konsumen gula semut dapat terpenuhi.

2. Perlunya antisipasi kenaikan harga bahan baku melalui identifikasi dan alternatif pemasok bahan baku lain yang dapat menyuplai kebutuhan perusahaan secara keberlanjutan sesuai harga yang bersaing di pasar.

3. Komunikasi antara perusahaan dan petani sangat penting untuk diperhatikan. Menjaga kepercayaan petani kepada perusahaan menjadi kunci untuk mengantisipasi kenaikan harga dari petani. Perusahaan sebaiknya meningkatkan harga bahan baku apabila harga produk di pasar meningkat.

\section{DAFTAR PUSTAKA}

Badiaroh, A. 2013. Budidaya Tanaman Kelapa. Medan (ID) : Balai Besar Perbenihan dan Proteksi Tanaman Perkebunan.

Gittinger, J.P. 1986. Economic Analysis of Agricultural Project terjemahan Sutomo S dan Mangiri K. 1986. Jakarta (ID) : Universitas Indonesia. 2nd Ed.

Husnan, S dan Muhammad, S. 2000. Studi Kelayakan Proyek. Penerbit Yogyakarta (ID) :AMP YKPN.Edisi Keempat.
Istiyanti E, Rahayu L, Sriyadi. 2018. Peran agroindustri lokal melalui peningkatan jaminan mutu produk dan pengelolaan keuangan. Jurnal Berdikari. 6(1) : 40- 52.

Lemantara J, Windarti T. 2014. Sistem Pendukung Keputusan Pengoptimalan Pembagian Tugas dengan Metode Assignment Berbasis Web [Jurnal]. Jurnal Nasional Teknik Elektro dan Teknologi Informasi Vol. 3, No.4, November 2014. Surabaya (ID): Sekolah Tinggi Manajemen Informatika dan Komputer Surabaya.

Mustaufik dan Karseno. 2004. Penerapan dan pengembangan teknologi gula kelapa kristal berstandar mutu SNI untuk meningkatkan pendapatan pengrajin gula kelapa di Kabupaten Banyumas. Laporan pengabdian masyarakat. Purwokerto (ID) : Universitas Jendral Soedirman.

Nurmalina R, Sarianti T, Karyadi A. 2014. Studi Kelayakan Bisnis. Bogor (ID): Institut Pertanian Bogor.

Palungkun, R. 2001. Aneka Produk Olahan Kelapa. Jakarta (ID): Penebar Swadaya.

Subagyo A. 2008. Studi Kelayakan. Jakarta (ID): PT Elex Media Komputindo.

Suhardiyono, L. 1995. Tanaman Kelapa. Yogyakarta (ID): Kanisius.

Wahyu, H. 2018. Analisis kelayakan usaha kangkung hidroponik di Specta Farm Kabupaten Bogor. [skripsi]. Bogor (ID): Institut Pertanian Bogor. 


\section{LAMPIRAN}

Lampiran 1. Hasil Penilaian Skor Kelayakan Aspek Pasar

\begin{tabular}{|c|c|c|c|c|c|}
\hline \multirow{2}{*}{ Item } & \multicolumn{5}{|c|}{ Skor Kelayakan Responden } \\
\hline & 1 & 2 & 3 & 4 & 5 \\
\hline Target pasar sudah tersedia & 4 & 4 & 4 & 5 & 4 \\
\hline Penjualan gula semut dilakukan secara kontinu & 4 & 4 & 4 & 5 & 4 \\
\hline Permintaan gula semut dari konsumen dapat terpenuhi & 5 & 5 & 4 & 4 & 4 \\
\hline Harga gula semut diterima oleh konsumen & 5 & 4 & 4 & 4 & 4 \\
\hline Perusahaan menguasai sebagian besar pasar gula semut di Kabupaten Kebumen & 5 & 5 & 4 & 5 & 4 \\
\hline Harga gula semut tidak mudah mengalami perubahan & 5 & 5 & 4 & 5 & 5 \\
\hline Promosi dilakukan untuk meningkatkan penjualan & 5 & 5 & 4 & 5 & 5 \\
\hline Harga jual gula semut mampu meningkatkan profit perusahaan & 5 & 5 & 4 & 5 & 4 \\
\hline Produk yang dihasilkan memiliki kualitas yang baik & 5 & 5 & 4 & 5 & 4 \\
\hline Distribusi produk berjalan lancar & 5 & 5 & 4 & 5 & 4 \\
\hline Jumlah & 48 & 47 & 40 & 48 & 42 \\
\hline Total & & & & & 225 \\
\hline Rata - rata & & & & & 45 \\
\hline Presentase (\%) & & & & & 90 \\
\hline
\end{tabular}

\section{Lampiran 2. Hasil Penilaian Skor Kelayakan Aspek Teknis}

\begin{tabular}{|c|c|c|c|c|c|}
\hline \multirow{2}{*}{ Item } & \multicolumn{5}{|c|}{ Skor Kelayakan Responden } \\
\hline & 1 & 2 & 3 & 4 & 5 \\
\hline Lokasi usaha sudah strategis dan dekat dengan pasar/pembeli & 4 & 4 & 2 & 5 & 4 \\
\hline Bahan baku yang dibutuhkan dekat dengan lokasi usaha & 4 & 5 & 4 & 5 & 4 \\
\hline Kebutuhan bahan baku dapat selalu terpenuhi dan harganya sesuai denga & & & & & \\
\hline harga pasaran & 4 & 4 & 2 & 4 & 4 \\
\hline Tenaga air dan listrik mudah didapatkan & 5 & 4 & 4 & 5 & 4 \\
\hline Adanya pelatihan tenaga kerja & 5 & 5 & 4 & 5 & 4 \\
\hline Fasilitas transportasi tersedia & 5 & 4 & 2 & 4 & 4 \\
\hline Tersedia peralatan dan mesin untuk produksi yang mudah dioperasikan & 5 & 5 & 4 & 5 & 4 \\
\hline Mesin berproduksi sesuai dengan kapasitasnya & 5 & 4 & 4 & 5 & 4 \\
\hline Perawatan terhadap mesin selalu dilakukan & 5 & 5 & 4 & 5 & 5 \\
\hline Proses produksi sudah sesuai standar & 5 & 4 & 4 & 5 & 4 \\
\hline Kapasitas produksi mampu memenuhi permintaan & 4 & 4 & 2 & 5 & 4 \\
\hline Penggunaan ruang produksi sudah digunakan dengan optimal & 5 & 4 & 4 & 5 & 4 \\
\hline Jumlah & 56 & 52 & 40 & 58 & 49 \\
\hline Total & & & & & 255 \\
\hline Rata-rata & & & & & 51 \\
\hline Presentase (\%) & & & & & 85 \\
\hline
\end{tabular}

Lampiran 3. Hasil penilaian skor kelayakan aspek manajemen dan hukum

\begin{tabular}{|c|c|c|c|c|c|}
\hline \multirow{2}{*}{ Item } & \multicolumn{5}{|c|}{ Skor Kelayakan Responden } \\
\hline & 1 & 2 & 3 & 4 & $\mathbf{5}$ \\
\hline Usaha yang dijalankan sudah berbadan usaha & 5 & 4 & 4 & 5 & 4 \\
\hline Terdapat struktur organisasi & 5 & 4 & 4 & 5 & 4 \\
\hline Tersedia tenaga kerja untuk masing-masing pekerjaan & 5 & 4 & 4 & 5 & 4 \\
\hline Setiap jabatan memiliki deskripsi pekerjaan & 5 & 4 & 4 & 5 & 2 \\
\hline Melakukan pengawasan terhadap kualitas kerja karyawan & 4 & 4 & 4 & 5 & 4 \\
\hline Memiliki surat mendirikan usaha & 5 & 4 & 4 & 5 & 4 \\
\hline Memiliki SPP-IRT (Sertifikat Produksi Pangan-Industri Rumah Tangga) & 5 & 4 & 4 & 5 & 4 \\
\hline Memiliki sertifikat dan IMB (Izin Mendirikan Bangunan) & 5 & 4 & 4 & 5 & 4 \\
\hline Perusahaan selalu membayar PBB (Pajak Bumi dan Bangunan) & 5 & 4 & 4 & 5 & 4 \\
\hline Perusahaan selalu membayar pajak penghasilan & 5 & 4 & 4 & 5 & 4 \\
\hline Jumlah & 49 & 40 & 40 & 50 & 38 \\
\hline Total & & & & & 217 \\
\hline Rata-rata & & & & & 43.4 \\
\hline Presentase (\%) & & & & & 86.8 \\
\hline
\end{tabular}




\section{Lampiran 4. Hasil Penilaian Skor Kelayakan Aspek Sosial dan Ekonomi}

\begin{tabular}{|c|c|c|c|c|c|}
\hline \multirow{2}{*}{ Item } & \multicolumn{5}{|c|}{ Skor Kelayakan Responden } \\
\hline & 1 & 2 & 3 & 4 & 5 \\
\hline $\begin{array}{l}\text { Adanya penambahan kesempatan kerja bagi masyarakat di lingkungan } \\
\text { perusahaan }\end{array}$ & 5 & 4 & 4 & 5 & 4 \\
\hline Daerah sekitar tempat usaha menjadi lebih ramai & 4 & 4 & 4 & 4 & 4 \\
\hline Sarana dan prasarana umum menjadi semakin baik & 2 & 4 & 4 & 4 & 2 \\
\hline Pendapatan masyarakat meningkat akibat adanya usaha & 4 & 4 & 4 & 5 & 4 \\
\hline Terjadi peningkatan kesejahteraan masyarakat & 4 & 4 & 4 & 5 & 4 \\
\hline Usaha diterima oleh masyarakat di lingkungan perusahaan & 5 & 4 & 4 & 5 & 4 \\
\hline Jumlah & 24 & 24 & 24 & 28 & 22 \\
\hline Total & & & & & 122 \\
\hline Rata-rata & & & & & 24.4 \\
\hline Presentase (\%) & & & & & 81.3 \\
\hline
\end{tabular}

\section{Lampiran 5. Hasil Penilaian Skor Kelayakan Aspek Lingkungan}

\begin{tabular}{|c|c|c|c|c|c|}
\hline \multirow{2}{*}{ Item } & \multicolumn{5}{|c|}{ Skor Kelayakan Responden } \\
\hline & 1 & 2 & 3 & 4 & 5 \\
\hline Usaha gula semut menghasilkan limbah padat cair atau gas & 2 & 4 & 4 & 4 & 2 \\
\hline Limbah yang dihasilkan tidak mencemari lingkungan & 5 & 4 & 4 & 4 & 5 \\
\hline Usaha memiliki tempat pembuangan limbah tersendiri & 4 & 4 & 4 & 4 & 2 \\
\hline Pengolahan limbah dilakukan oleh perusahaan & 4 & 4 & 4 & 4 & 4 \\
\hline Keamanan di lingkungan usaha dapat terjaga & 5 & 5 & 4 & 4 & 4 \\
\hline Jumlah & 20 & 21 & 20 & 20 & 17 \\
\hline Total & & & & & 98 \\
\hline Rata-rata & & & & & 19.6 \\
\hline Presentase (\%) & & & & & 78.4 \\
\hline
\end{tabular}

